\title{
ERRORS IN QQ ONLINE CHATTING: A STUDY ON CHINESE ESL LEARNERS IN INDONESIAN UNIVERSITY
}

\author{
Desi Rohayati;*Erlyna Abidasari. \\ University of Muhammadiyah Malang - INDONESIA \\ Desirohayati08@gmail.com \\ erlynaabidasari@umm.ac.id
}

\begin{abstract}
This study intends to investigate errors found in an online written platform used by Chinese students in English Language Education Department. The online platform observed in this study was QQ chatting, where students freely and without pressure utilize the application for everyday English communication. Most Chinese students have performed unorganized sentence patterns, resulting in meaning breakdown. This study employed qualitative case study design with five Chinese respondents. The researchers were actively involved in the QQ chatting as the participants; the discussion topics revolved around everyday communication topics, namely academic life, friendship, social interaction, and culture challenges. The data then were recorded weekly for one semester and analyzed through manuscript analysis from the recorded captures of the conversations. The findings suggest that there were various types of errors performed by Chinese students: omission, misformation, addition, misordering, and mixed-types. The most prominent one was omission with the total of twenty-eight times occurrence. The omission errors were divided into omission of nouns as in 'today have sunshine', omission of verbs as in 'I don't know here will so cold', omission of auxiliary verbs as in 'I eaten dinner' and omission of verb inflections as in 'Where are you go?'. The most commonly found omissions errors were due to the influence of Chinese first language where the speakers have totally different tenses and sentence organization with English.
\end{abstract}

Keywords: Error, Chinese Learners, $Q Q$ Online Chatting, Indonesian University

\section{INTRODUCTION}

$Q Q$ is recognized as the most popular internet-based instant messaging device designed by Tencent Holding LTD, developed with Chinese characters on early 1999 (Zhang, 2010). $Q Q$ offers multi-device log-in similar to other common social media such as Facebook, Twitter, and WeChat. QQ can be accessed through Windows, iOs/iPhone and Web. Nowadays, $Q Q$ enables its service using English language with $Q Q$ International application. $Q Q$ social media is selected in this research as it is known as an accessible and most popular social media in China exceeding the performance of WeChat(Zhang, 2010). $Q Q$ social media provides several features such as live translation, online find friends, sharing moments and multi communication. Multi communication is the main feature of $Q Q$; it includes video and voice call, as well as online chat.

The platform for online chat is a real-time communication over the Internet between people in text messages by using social media as tools. In addition, Peris et al. 
(2002) describe that online chat room is a meeting point, allowing people to communicate with others. Hence, Internet connection is highly required for the performance. Commonly, chat messages are short in order to get fast response from another chat participant. Furthermore, chat is conducted in the written form which is related to the writing skill. As stated by Beason and Lester (2012), the important part of writing is sentence organization. Besides, it has a significant downside element to be identified easily, namely: error.

Error occurred because people have difficulties in implementing the rule of certain language. Errors are easily found in sentences or phrases. There are several error areas such as omission errors, misformation, addition, and misordering errors. Errors are basic features of second language or foreign language learning process. The error made by non-native speakers is commonly influenced by their first language as covered in language transfer (Beason and Lester, 2012).

The first language of English learners in China is Chinese standard language (pütōnghuà), while English is considered as the second language. In language learning, errors are not regarded as something to be avoided but as a coherent part of the language learning process for students. An error is created as an indication that learners still work their way in a learning process. In addition, comprehending errors are deemed significant in order to understand the problems in using the target language, specifically the implementation of English language by Chinese students.

This research was conducted to investigate typical errors in $Q Q$ online chatting on the informal situation by Chinese students experiencing course exchange in one of the notable universities in Malang, East Java, Indonesia. The investigated errors in this research were focused on the sentence and phrase levels. The matter of error in informal situation wasseen as a problem which led negatives impact, such as misunderstanding and incorrect application of sentence organization in academic writing or formal writing.

This study aims to investigate the typical errors found in an online written platform used by Chinese students in English Language Education Department. The research problem is "what are the errors performed by Chinese students of English Language Education Department in QQ chat platform?"

\section{METHODS}

Qualitative case study design was implemented to analyze the typical error performed by Chinese students. A research object is related to scientific work that is being investigated. $Q Q$ social media chats were the main object of the research, while five participants from China who enrolled in the course exchange program academic year 2017/2018 were invited. The discussion topics revolved around everyday communication topics, namely academic life, friendship, social interaction, and cultural 
challenges faced by 5 Chinese students who are involved in this research. The data then were recorded weekly for one semester and analyzed through manuscript analysis from the recorded captures of the conversations. Document analysis was conducted; focusing on phrases and sentence formations taken from the screen capture of the QQ conversation among participants.

\section{FINDINGS AND DISCUSSION}

\section{FINDINGS}

The result of analysis showed that the researcher discovered 48 errors occurred in the QQ chat platform performed by Chinese students of English Language Education Department. Those errors were classified into omission, misformation, addition, misordering, and double types of errors. Each of the error types were also put in several categories, the examples of each errorsmentioned are in the following table:

Table 3.1 Examples of Errors Performed by Chinese Students

\begin{tabular}{|c|c|c|c|}
\hline No & Type of Errors & $\begin{array}{l}\text { Incorrect Phrase/ } \\
\text { Sentence }\end{array}$ & Correct Phrase/ Sentence \\
\hline \multicolumn{4}{|c|}{ Omission Errors } \\
\hline 1 & Omission of Noun & Today have test & Today I have test. \\
\hline 2 & Omission of Verb & $\begin{array}{l}\text { I do not know here will so } \\
\text { cold }\end{array}$ & $\begin{array}{l}\text { I do not know here will be } \\
\text { so cold. }\end{array}$ \\
\hline 3 & $\begin{array}{l}\text { Omission of Auxiliary } \\
\text { Verb }\end{array}$ & $\begin{array}{l}\text { Actually today not my } \\
\text { birthday }\end{array}$ & $\begin{array}{l}\text { Actually today is not my } \\
\text { birthday. }\end{array}$ \\
\hline 4 & $\begin{array}{l}\text { Omission of Verb } \\
\text { Inflection }\end{array}$ & I m stay at home & I am staying at home. \\
\hline 5 & $\begin{array}{l}\text { Omission of Noun and } \\
\text { Auxiliary Verb }\end{array}$ & $\begin{array}{l}\text { When I work he want } \\
\text { video call }\end{array}$ & $\begin{array}{l}\text { When I am working, he } \\
\text { wants video call. }\end{array}$ \\
\hline 6 & $\begin{array}{l}\text { Omission of Auxiliary } \\
\text { verb and Possessive } \\
\text { Adjective }\end{array}$ & $\begin{array}{l}\text { Maybe everyday you with } \\
\text { computer together? }\end{array}$ & $\begin{array}{l}\text { Maybe everyday, are you } \\
\text { with your computer } \\
\text { together? }\end{array}$ \\
\hline 7 & $\begin{array}{l}\text { Omission of Question } \\
\text { Mark }\end{array}$ & How are you & How are you? \\
\hline \multicolumn{4}{|c|}{ Misformation Errors } \\
\hline 8 & $\begin{array}{l}\text { Misformation of } \\
\text { Singular and Plural } \\
\text { form }\end{array}$ & $\begin{array}{l}\text { This days I am doing } \\
\text { report same with you }\end{array}$ & $\begin{array}{l}\text { This day I am doing } \\
\text { report, same with you. }\end{array}$ \\
\hline 9 & Misformation of Article & I'm going to a interview & I'm going to an interview. \\
\hline 10 & Misformation of Verb & What did she said? & What did she say? \\
\hline 11 & $\begin{array}{l}\text { Misformation of } \\
\text { Pronoun }\end{array}$ & Im English is very bad & My English is very bad. \\
\hline \multicolumn{4}{|c|}{ Addition Errors } \\
\hline 12 & Addition of Auxiliary & That's time is too late & That time is too late. \\
\hline
\end{tabular}




\begin{tabular}{|c|c|c|c|}
\hline & Verb & & \\
\hline 13 & $\begin{array}{l}\text { Addition of Verb } \\
\text { Inflection }\end{array}$ & $\begin{array}{l}\text { Every day I teaching } \\
\text { students }\end{array}$ & Every day I teach students. \\
\hline \multicolumn{4}{|c|}{ Misordering Errors } \\
\hline 14 & Interrogative Sentence & $\begin{array}{l}\text { You have completed } \\
\text { yours? }\end{array}$ & $\begin{array}{l}\text { Have you completed } \\
\text { yours? }\end{array}$ \\
\hline \multicolumn{4}{|c|}{ Double Types of Errors } \\
\hline 15 & $\begin{array}{l}\text { Omission \& } \\
\text { Misformation Error }\end{array}$ & Its ok & It is ok. \\
\hline 16 & $\begin{array}{l}\text { Addition \& Omission } \\
\text { Error }\end{array}$ & It is will busy & It will be busy. \\
\hline 17 & $\begin{array}{l}\text { Misformation \& } \\
\text { Addition Error }\end{array}$ & $\begin{array}{l}\text { Tomorrow we can back to } \\
\text { home }\end{array}$ & $\begin{array}{l}\text { Tomorrow we can go back } \\
\text { home. }\end{array}$ \\
\hline 18 & $\begin{array}{l}\text { Omission \& Other } \\
\text { Error }\end{array}$ & $\begin{array}{l}\text { Do you want come to } \\
\text { china? }\end{array}$ & $\begin{array}{l}\text { Do you want to come to } \\
\text { China? }\end{array}$ \\
\hline 19 & $\begin{array}{l}\text { Misformation and Other } \\
\text { Error }\end{array}$ & ... how are your mandarin? & ..., how is your mandarin? \\
\hline 20 & $\begin{array}{l}\text { Addition and Other } \\
\text { Error }\end{array}$ & $\begin{array}{l}\text { What do you wanna from } \\
\text { laos? }\end{array}$ & $\begin{array}{l}\text { What do you want from } \\
\text { Laos? }\end{array}$ \\
\hline
\end{tabular}

a. Omission Errors

In omission error, the researcher discovered 28 errors performed by Chinese students of the English Language Education Department. Those errors were classified into 7 categories. The first category of omission error discovered in the chat was omission of noun (3 errors) and most of the missing noun errors were the subject noun. As seen in the Table 1 (No. 1), the example of the error is in the sentence today have test, which correct form should be today I have test. Other categories of omission errors discovered in this research were 2 omissions of verb, 10 omissions of auxuliary verb, 3 omissions of verb inflection, 4 omissions of noun and auxiliary verb, 1 omission of auxiliary verb and possessive adjective, and 6 omissions of question mark.

\section{b. Misformation Errors}

In misformation error, the researcher discovered 6 errors performed by Chinese students of English Language Education Department.Those misformation errors were classified into 4 categories, namely: misformation of singular and plural form (1 error), misformation of article (1 error), misformation of verb (2 errors), and misformation of pronoun ( 2 errors). One example of misformation error found in the chat were the incorrect use of article. As seen in Table 1 (No. 9), the incorrect sentence was I'm going to a interview, the word interview is pronounced as a vowel in the first word. The article used before the word interview should be an. Therefore, the correct sentence should be I'm going to an interview.

c. Addition Errors 
In misformation error, the researcher discovered 3 errorsperformed by Chinese students of English Language Education Department. Those errors were classified into 2 categories, namely: addition of auxiliary verb ( 2 errors) and addition of verb inflection (1 error). One example of addition error found in the chat were the addition of verb inflection. As seen in the Table 1 (No. 13), the incorrect sentence was ever day I teaching students. The use of adverbevery day explains a habit that should be followed by simple present tense. The inflection +ing in word teaching is unnecessary. Therefore, the correct sentence should be every day I teach students.

\section{d. Misordering Errors}

In misordering error, the researcher discovered 1 error in the interrogative sentence. As seen in the Table 1 (No. 14), the sentence You have completed yours? is a yes-no interrogative sentence of present perfect tense. Yes-no question normally begins with auxiliary verb. In this sentence, the auxiliary verb is have. In this case, misordering error is located in the placement of auxiliary verb. Therefore, the correct sentence should be have you completed yours?.

\section{e. Double Types of Errors}

In the double types of error, the researcher discovered 9 errors errorsperformed by Chinese students of English Language Education Department. This type of errors occurred as the researcher found that there were two types of error in a sentence. Those errors were classified into 5 categories, namely: Error of omission and misformation (4 errors), error of addition and omission ( 2 errors), error of omission and other (1 error), error of misformation and other ( 1 error), and error of addition and other ( 1 error). Other errors found in the chat were errors that occurs in the use capitalization of name of country.

\section{DISCUSSION}

In this research, the researcherinvestigatederrors which is defined as natural phenomenonoccurred along with the learning process especially in learning foreign language. The errors wereperformed by the Chinese students of English Language Education Department in QQ chat platform where English is not their everydaylanguage. Their first language is Mandarin Language. Besides, the language which is considered as foreign is English language. Therefore, the researcher found many errors in the useof English language.

The errors not only occurred in phrases and sentences. The types of error were omission, misformation, addition, misordering, and other errors. Other error in this research was only identified in the incorrect capitalization as Beason \& Lester (2012) stated that capitalization is important in a sentence. The capitalization error was located 
in the first letter of country's name (*laos which should be Laos). The most dominant error occurred in the omission error of auxiliary verb. This type of error is considered as an influence of Chinese students' first language (Chinese standard language) which has no tenses in its sentence organization.

\section{CONCLUSION AND SUGGESTION}

In conclusion, the researcher found 48 errors which were classified into 5 types, namely omission, misformation, addition, misordering, and double types of error. In short, there were 28 errors in the omission errors, 5 errors in misformation errors, 3 errors in addition errors, 1 error in misordering error and 11 errors in double types of error. The most dominant error was performed in the error of omission which appears 28 times, specifically it was performed 10 times in the omission of auxiliary verb. This error frequency would be problematic if the participants do not realize and fix their errors by the help of others (such as the researcher). Therefore, immediate use of different version of QQ online needs to be fostered. International QQ was one of the solutions where the users can directly use English in their application, giving more chance for Chinese learners to actively participate and correct their English. Adequate class conversation in English as well as group project using international QQ should be implemented by the lecturer in order to provide ample examples and practices for the participants.

\section{REFERENCES}

Beason, L.,\& Lester, M. (2012). A Common Sense Guide to Grammar and Usage (6 $^{\text {th }}$ ed.). New York, USA: Bedford/ St. Martin's.

Brown, D. (2000). Principles of Language Learning and Teaching (4 ${ }^{\text {th }}$ ed). San Francisco, USA: Longman.

Gass, S. M., \& Selinker, L. (2008). Second Language Acquisition: An Introductory Course( $3^{\text {rd }}$ ed.). New York: Routledge.

Limengka, P.E.,\& Kuntjara, E. (2012). Types of Grammatical Errors in the Essay

Written by Fourth-Semester Students of English Department, Petra Christian

University. Journal of Literature, Language, and Teaching, 1(1). 230-238.Retrieved from: eprints.uny.ac.id/25706/

Meriläinen, L.(2010). Syntactic Transfer in the Written English of Finnish Students: Persistent Grammar Errors or Acceptable Lingua Franca English?Journal of Applied Language Studies, 4(1). 51-64. Retrieved from: https://jyx.jyu.fi/ 
Muriungi, P. K., Mukuthuria, M., \& Gatavi, M. (2011). Education and Language: Errors in English Language and Their Remedies. The Journal of Language and Linguistic Studies, 7(2). 87-116. Retrieved from: http://dergipark.ulakbim.gov.tr/

Saville-Troike, M. (2006). Introducing Second Language Acquisition. Cambridge, Cambridge University Press.

Sayeed, I. (2016). Error Analysis in Writing: A Comparative Study of Bangla Medium and English Medium Schools in Dhaka. (Master Degree Thesis, BRAC University Dhaka).Retrieved from: http://hdl.handle.net/10361/2076

Peris, R., Gimeno, M. A., Pinazo, D., Ortet, G., Carrero, V., Sanchiz, M., \& Ibáñez, I. (2002). Online Chat Rooms: Virtual Spaces of Interaction for Socially Oriented People. Journal of Cyberphsycology \& Behavior, 5(1). 43-51. doi: $\underline{10.1089 / 109493102753685872}$

Yule, G. (2010). The Study of Language (4 ${ }^{\text {th }}$ ed). London: Cambridge University Press. Retrieved from: www.cambridge.org/

Zhang, M. (2010). Tencent $Q Q$. Retrieved from: www.econ.ucla.edu/

Zheng, C., \& Park, T. J. (2013). An Analysis of Errors in English Writing Made by Chinese and Korean University Students. Journal of Theory and Practice in Language Studies, 3(8). 1342-1351. doi:10.4304/tpls.3.8.1342-1351 